\title{
A Review of Pancasila under Globalization
}

\author{
Al Khanif, Mirza Satria Buana, Manunggal Kusuma Wardaya (Eds). Pancasila Dalam \\ Pusaran Globalisasi (LKiS, 2017) pp. xviii + 440. Paperback: IDR 150.000
}

\author{
Shofi Munawwir Effendi \\ University of Jember, Indonesia \\ shofimunawwir.e@gmail.com
}

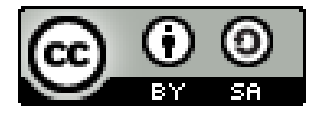

Copyright $\odot 2019$ by Author(s)

This work is licensed under a Creative Commons Attribution-ShareAlike 4.0 International License. All writings published in this journal are personal views of the authors and do not represent the views of this journal and the author's affiliated institutions.

\section{HOW TO CITE:}

Effendi, Shofi Munawwir. "A Review of Pancasila under Globalization" (2019) 6:3 Lentera Hukum 463-468.

Submitted: May 24, 2019 Revised: June 04, 2019 Accepted: November 18, 2019

Pancasila dalam Pusaran Globalisasi (Pancasila under Globalization) is a book that aims to see Pancasila, Indonesia's state ideology, from a global perspective. This book suggests readers consider the role of Pancasila over the world's powers of other ideologies by presenting rare insights to discuss and bridge the understanding of continuities and changes that has existed in society. Changes include, but not limited, to social, political, economic change, and linkages with various variations of society. Those changes are massively happening in the era of globalization plus with the challenges of the government to filter it. ${ }^{1}$ This book is a compilation of writings from various excellent academics in their fields. Moh. Mahfud MD, foremost Indonesia's professor of law and politics, delivered the book's prologue, who critically questioned 'Is Pancasila still relevant?' in the era for which Pancasila is rarely seen to implement in public life. Given the fact that hitherto Indonesia has faced problems that have come out of the nature of Pancasila. Mahfud, in his prologue, asked the reader to reflect on the true meaning of Pancasila. In short, understanding the role of Pancasila in this globalized world, particularly as the nation's ideology, has become essential so that every Indonesian citizen will have a much more similar understanding, perception, and attitude towards Pancasila. ${ }^{2}$

1 Winner Agung Pribadi, "Sumbangan Perspektif Gramscian dalam Memahami Gerakan Globalisasi Alternatif" (2008) 115 at 35.

2 Satrio Budiwibowo, "Revitalisasi Pancasila dan Bela Negara Dalam Menghadapi Tantangan Global Melalui Pembelajaran Berbasis Multikultural" (2016) 4:2 Citizenship Jurnal Pancasila dan Kewarganegaraan 565 at 567. 
This book has five neatly arranged chapters. The five chapters are as follows: first overviews Pancasila, religion, and globalization; second critically discusses Pancasila, radicalism, and ideology; third examines Pancasila as an inclusive ideology in globalization; fourth revisits Pancasila, state sovereignty and globalization; and the last deals with an analysis on Pancasila, justice and democracy in globalization. Overall, most authors think that Pancasila, in this contemporary time, remains challenging. New unprecedented challenges, as they mostly discussed, however, still could be managed under the national interest. The rise of ultra-nationalist forces and religious radicalism has led to internal conflicts within a country. It indicates that internal conflicts and horizontal conflicts threaten Indonesia. All the writings written by academics in this book can dissect them one by one.

The first chapter has three sub-themes - Pancasila, religion, and globalization - and consists of five writings. This chapter focuses on explaining the concept of religion, which most of the time intersect with the Pancasila. It also deals with the relation of religion and the process of globalization in Indonesia. When discussing religion, it is hard not to include the process of globalization since religion has become the identity of every citizen. Due to globalization, religion flourishes as an identity, and it is also a pride that needs to disseminate. As a result of globalization, however, a shift in understanding the meaning of religion for religious adherents is undeniable. Besides, the challenge of religious globalization presents a challenge that is the rise of fundamentalism ${ }^{3}$ in religion that threatens the values and norms of people's lives. It presents a culture of "them" and "us" that gave rise to the division of religious groups in society. There are groups of friends and followers of different groups being opponents and threats. It has a destructive effect that should be abandoned to turn to ethical issues and assume that the enemies of religion are not followers of other religions, but poverty, ignorance, and other global problems. ${ }^{4}$

The rights to hold religion of the people are being tested, even though it is apparent in the first precepts that Pancasila states that 'God Almighty' is an acknowledgment of God, which is the constitutional rights of every citizen guaranteed by our constitution. So, it is clear that Indonesia is neither a secular nor a religious state. ${ }^{5}$ Therefore, all systems in Indonesia should be suitable for all religions, not just one particular religion. Here diversity is called into question, that we cannot deny pluralism. In chapter 1 , all the writings succeeded in making the reader think openly by presenting actual and developing facts and data.

The second chapter is started with an article titled Pancasila in the Transnational Islamic Vortex. The relationship between Islam and Pancasila, which is often clashed in the Indonesian constitutional system, is ignored by Muslim thinkers, one of whom is Gus Dur, who is known as the Chinese Father of Indonesia ${ }^{6}$ or the Father of Pluralism. However, it

3 "Agama: Antara Fundamentalis dan Moderat," online: www.uin-malang.ac.id 〈https://www.uin malang.ac.id/blog/post/read/15ll0l/agama-antara-fundamentalis-dan-moderat.html>.

Arqom Kuswanjono, "Pluralisme Pancasila" (2017) 16:1 Jurnal Filsafat 77 at 91.

5 Masykuri Abdillah, "Hubungan Agama dan Negara dalam Konteks Modernisasi Politik di Era Reformasi" (2013) 13:2 AHKAM : Jurnal Ilmu Syariah, online: 〈http://journal.uinjkt.ac.id/index.php/ahkam/article/view/937〉 at 250.

6 Kumparan, "Gusdur 'Bapak Tionghoa Indonesia'," online: kumparan 〈https://kumparan.com/potongannostalgia/gusdur-bapak-tionghoa-indonesia>. 
does not necessarily abolish the parties who want Indonesia based on Islamic ideology. The discourse on the establishment of the Islamic State of Indonesia is an old song that has been repeating since the strengthening of Hizbut-Tahrir Indonesia, which wants countries in the world to unite in one leadership, Khilafah. The formation of a global Khilafah is a significant emphasis on the struggle of Hizbut-Tahrir. ${ }^{7}$ This illusion of power struggle based on religion is possible. The efforts of radical groups to destroy Indonesia should be watched out for because many radical Islamic movements are calling for a return to pure Islamic teachings. ${ }^{8}$ Pancasila, as the basis of state philosophy, state ideology, and way of life, should be implemented in practice. New ideologies have infiltrated Indonesia in the era of globalization.

When the first and second chapters focus more on the challenge of the solidity of the first principle of the Pancasila, it is different from the third chapter, which is more widespread and philosophical. There are five exciting titles to read. The focus of topics on the first and second posts is on ideology. In the first article discusses Pancasila as a living ideology, and the second article is Pancasila, the ideology of a torn nation can be understood that the functions and values of Pancasila are actually under the views and ideals of the life of the nation and state of Indonesia. However, what needs to be considered is when there is a denial of the Pancasila itself. Pancasila, which until now stands tall, does not necessarily just stand firm. There are many conflicts and excessive exposure. The concrete form is the rejection of Pancasila as a mandatory principle in several community organizations. In fact, Hizbut-Tahrir Indonesia, which is a banned social organization, is currently the most enthusiastic about voicing the rejection of Pancasila as an organizational principle. Opinions and differing views must be respected; however, the unthoughtful paths and steps taken are the problem. The 1945 Constitution accommodates freedom of association and opinion. As a manifestation of Pancasila, freedom should not necessarily be without limits. ${ }^{9}$

Pancasila is regarded as the soul of the Indonesian people who are the deciding elements of the rule of law and the fundamental principles of state law. ${ }^{10}$ As a source of law, outlook on life, and the ideals of the nation, Pancasila always experiences a variety of significant collisions. Nowadays, Pancasila is expected to have an opportunity to interact with changes and developments that occur. Bearing in mind, Pancasila is a forum for openness and differences in the dynamic nature of an ideology. It shows the role of Pancasila to protect national identity. In this third chapter, various writings show that Pancasila is used as an ideology of an inclusive state, not only applicable to vertical interests but also horizontal. Pancasila tries to protect differences, diversity, and give an inclusive and tolerant nuance to global society.

The fourth chapter discusses the relation between the Indonesian economy with food sovereignty and the sovereignty of natural resources belonging to the people. A reliable

Syamsul Rijal, "Radikalisme Islam Klasik dan Kontemporer: Membanding Khawarij dan Hizbut Tahrir" (2010) 1418 at 221.

8 Ibid at 215.

9 Muhammad Bahrul Ulum \& Nilna Aliyan Hamida, "Revisiting Liberal Democracy and Asian Values in Contemporary Indonesia" (2018) 4:1 CONSREV 111 at 125.

10 Agung Dwi Kurniawan, "Hubungan Proklamasi dengan Pancasila dan Pembukaan Undang-Undang Dasar $1945 "$ at 178. 
stream of liberalization has shifted local products and changed the system to become more liberal. This liberalization also helped shift national economic policy to be obliged to adjust to global rules. The domestic market has become more open to international business competition. " Thus, it becomes the duty and role of the state to set the policy and state institutions. The regulation of economic liberalization is not by way of rejection. Instead, various policies must still be based on Pancasila without the need to uphold liberalization excessively. Both are not things that need to be disputed, but the Pancasila economic system must be open with its domestic affairs. As a form of guaranteeing shared prosperity, the implementation of Article 33 of the 1945 Constitution mandates that the government maximizes its role and control. It is necessary as a form of utilization of natural resources for the protection and necessities of life of many people.

Indeed, Globalization has several negative impacts, but it cannot be denied that it is economically beneficial, namely the implementation of international trade and that it can be in the form of a cultural cross-culture. At the same time, the impact of globalization also affects how people interact with people, between countries or regions in the world. Globalization is a system that cannot be contained by humans. Indeed, there are various negative impacts and rejection of globalization throughout the world. The power of antiglobalization is associated with the anti-capitalist movement. However, the needs of the community in utilizing the products of globalization have become a major factor in the existence of globalization. ${ }^{12}$ Openness and ease of access are what drives us inevitably, like it or not, enter into the vortex of globalization. Pancasila, as the spirit of the nation, will bring to the diversity of its people to be wise and prudent in facing globalization. In the end, the noble values of Pancasila are not just a false ideology; the country's sovereignty becomes strong when Pancasila stands as an attitude and ideals of the nation.

The last part of this 440-page book is chapter V with the sub-theme Pancasila Justice and Democracy in the Era of Globalization. Pancasila ideology has firm roots in every life as a nation and state. As a modern democracy, the Indonesian constitution places Pancasila as the ideological and philosophical basis of the nation and state. Thus, the constitutional and legal systems in Indonesia must not conflict with the values contained in Pancasila. In this fifth chapter, the closing topic presents the discussion of Pancasila as a benchmark and national state view. There are five writings on the dynamics of Indonesian state administration, both in terms of legislation, state institutions, constitutional justice in Indonesia, to the system of change or transfer of power of national leadership. The role of Pancasila is a solution to the imperfection of laws and regulations in Indonesia. Therefore, it is evident that Pancasila is the philosophy of public life that must not be abandoned and forgotten as a foundation in the nation and state. ${ }^{13}$

All values in each precept are described in each of the written topics available in this book. With an exciting topic and language that is understandable, this book is worth reading and used as an educational reference. Indeed, this compilation of various writing

11 B Kuspradono \& B Kuspradono, "Kritik Terhadap Konsep Pembangunan Ekonomi 'Neoliberal” (2016) 7 KINERJA 165 at 181.

12 Pribadi, supra note 1 at 25.

13 Hariyono, "Ideologi Pancasila: Roh Progresif Nasionalisme Indonesia" (Malang: Intrans Publishing, 2014) at 127. 
books looks a lot and boring. Sub-themes in each chapter are considered too rigid. However, the authors believe that the book's editorial team and contributors have tried to make a concept that is concise but concise and clear. The writing style of each contributor's academics cannot be generalized. It is through this difference in delivery that this book is unique. It is precisely with differences that enrich the thinking and enrich the treasures of this book. 
468 | A Review of Pancasila under Globalization

This page is intentionally left blank 